2012

\title{
What Useful Role (If Any) Could Legal Positivism Play in the Study or Advancement of International Law?
}

Mortimer N.S. Sellers

University of Baltimore School of Law, msellers@ubalt.edu

Follow this and additional works at: http://scholarworks.law.ubalt.edu/all_fac

Part of the International Law Commons, and the Law and Philosophy Commons

\section{Recommended Citation}

What Useful Role (if any) Could Legal Positivism Play in the Study or Advancement of International Law?, 106 Am. Soc'y Int'1 L. Proc. 373 (2012).

This Article is brought to you for free and open access by the Faculty Scholarship at ScholarWorks@University of Baltimore School of Law. It has been accepted for inclusion in All Faculty Scholarship by an authorized administrator of ScholarWorks@University of Baltimore School of Law. For more information, please contact snolan@ubalt.edu. 
according to the suggested model, these all ought to conform to the general, normatively unifying rule of recognition-understood to include the requirements of justice, clarity, publicity, certainty, equality, fairness, the principle of pacta sunt servanda, and perhaps also "elementary conditions of humanity," to mention just a few. ${ }^{8}$

\section{CONCLUDING REMARKS}

I have aimed in these brief remarks to sketch some parameters of a possible model for theorizing sources of international law through the lens of inclusive positivism. Admittedly, many issues remain untouched, for example, distinguishing - if possible-between the formation and application of sources; the (ir)relevance of consensus of international actors regarding a source; the (Hartian) internal point of view of those actors; and the hierarchy of sources themselves, to note a few that call for further elaboration.

The main impetus here has been to point to the necessity of a coherent theory of sources in international law which allows for flexibility, while setting a conceptual framework that explains developments in the social practice of international law. To do this comprehensively, we may have to acknowledge the pluralist—or fragmented, as some may call it-nature of international law: different fields or regimes have developed their own methodology of making law. At the same time, noting that the rule of recognition must be settled to some extent to avoid ambiguous outcomes, I suggest, as other scholars have done before me, some minimal substance to it that then validates norms of law. ${ }^{9}$ In general, the presupposition in these remarks is that international law has in fact evolved into a legal system consisting of identifiable primary and secondary rules, and a meta-rule-the rule of recognition-even if not yet a fully fledged one.

I have thus aimed to illustrate how morality may be a determining factor of the legality of rules and of sources by suggesting some building blocks for future evaluation and exploration of sources theory in international law. Ultimately, the question comes back to whether we should persevere with the state consent-based theory of sources, or work toward a theory that reflects the new reality - a reality where we are no longer conducting international affairs and international law according to the models and methodologies that arose from the postSecond-World-War-anxieties, but are using the models and methodologies arising from today's much more multi-layered, and hence complex, society.

\section{What Useful Role (if any) Could Legal Positivism Play in the STUdy OR ADVANCEMENT OF INTERNATIONAL LAw?}

\section{By Mortimer N.S. Sellers*}

What useful role (if any) could legal positivism play in the study or advancement of international law? For most of those who remember this once fashionable term at all, "international legal positivism" is redolent of the early years of the twentieth century-of

\footnotetext{
${ }^{8}$ See, e.g., Besson, supra note 1, at 172; Ruti G. Teitel, Humanity's Law 170 (2011); Lon Fuller, The Morality of Law 39 (1964); David Luban, The Rule of Law and Human Dignity: Re-examining Fuller's Canons, 2 Hague J. ON Rule L. 29 (2010); David Lefkowitz, The Sources of International Law: Some Philosophical Reflections, in The Philosophy of InTernational Law, supra note 1, at 187, 189-91.

${ }^{9}$ As Coleman notes: "[T] $]$ he more controversial the rule of recognition, the less able it is to provide guidance .

. 'Coleman, supra note 2, at 118.

* Regents Professor of the University System of Maryland; Director, University of Baltimore Center for International and Comparative Law (mortimer.sellers@gmail.com).
} 
Lassa Oppenheim ${ }^{1}$ at best, and at worst of his model, John Austin, who famously denied that international law is or ever could be genuine law at all, "properly so called."2 "Positive" law in its central and most usual sense is law "set by a sovereign individual or a sovereign body ... to a person or persons in a state of subjection to its author,"3 and legal "positivism", is the doctrine that there is and can be no law but positive law. Seen in this way, international law, which rests substantially on opinio juris and "the general principles of law recognized by civilized nations," 5 will never fit the positivist paradigm. ${ }^{6}$

So why revive international legal positivism? I would suggest that despite its longstanding antipathy toward international legality and its radical failure as a general theory of law, legal positivism has always played a useful role in the progressive development of international legal institutions. Positive law has been part of international law from the beginning and will become increasingly important as international institutions become stronger. Legal positivism is a powerful tool for bringing greater clarity into international law. The better and more just the constitution of international society becomes, the more important and useful international legal positivism will be.

\section{INTERNATIONAL LAW}

The traditional understanding of international law was well-stated by Henry Wheaton when John Austin made his first positivist attack on the law of nations: "International law, as understood among civilized nations, may be defined as consisting of those rules of conduct which reason deduces, as consonant to justice, from the nature of the society existing among independent nations; with such definitions and modifications as may be established by general consent." 7 The basis of international law rested for Wheaton, as for the earlier great publicists Hugo Grotius ${ }^{8}$ and Emer de Vattel, ${ }^{9}$ on reason and human nature, subject to specification by agreement. The clarifying provision of "definitions and modifications" by consent is the basis of "positive" international law.

Modern international law began with Hugo Grotius, whose turn to reason and the common good supplanted earlier sectarian conceptions of the law of nations. "All of this would still be true," Grotius insisted, "even if there were no God." 10 Grotius found international law in the social nature and mutual obligations of humanity, applied to states. " Emer de Vattel, who revised and restated in accessible French the Latin doctrines of Grotius and Christian Wolff, ${ }^{12}$ asserted that precisely because international society has no authority capable of

${ }^{1}$ Lassa Oppenheim, International Law: A Treatise (1905).

2 John Austin, The Province of Jurisprudence Determined 148 (1832).

${ }^{3} I d$. at 6.

${ }^{4} I d$. at 148 .

${ }^{5}$ See, e.g., Statute of the International Court of Justice, Art. 38, and its antecedents in Henry WhEATON, ElEMENTS OF INTERNATIONAL LAW 23-27 (1836).

${ }^{6}$ See, more recently, H.L.A. HART, The CONCEPT of LAw 208-31 (1961).

${ }^{7}$ WHEATON, supra note 5 , at 23.

${ }^{8}$ Hugo Grotius, De Iure Belli ac Pacis Libri Tres in Quibus Jus Naturae et Gentium, item Juris Publici Praecipua Explicantur (new ed. 1646), prolegomena $\$ 11$.

${ }^{9}$ Emer de Vattel, le Droit des Gens, ou Principes de la Loi Naturelle Appliqués à la Conduite et aux Affaires des Nations et des Souverains, at xxi ff (1758).

10 "Et haec quidem quae jam diximus, locum aliquem haberent, etiamsi daremus quod sine summo scelere dari nequit, non esse Deum, aut non curare ab eo negotia humana." Grotıus, supra note 8, prolegomena, $\$ 11$.

11 "Haec vero, quam rudi modo jam expressimus societatis custodia, humano intellectui conveniens, fons est ejus juris, quod proprie tali nomine appellatur."' $I d$., prolegomena.

12 Christian Wolff, Jus Gentium Methodo Scientifica Pertractatum (1764). 
commanding its members and forcing obedience, ${ }^{13}$ states are bound first and foremost by "necessary" laws that arise from the natural society of human beings. ${ }^{14}$

Vattel identified four varieties of international law. The "necessary" law of nations arises directly from reason, applied to the nature of men and states. ${ }^{15}$ The "voluntary" law of nations protects the zone of liberty and independence within which states may depart from reason, provided they do no injury to others or the common good. ${ }^{16}$ The "conventional" law of nations concerns the obligations that nations assume by treaty, binding only on the contracting parties. ${ }^{17}$ And the "customary" law of nations is founded on tacit agreement among those nations who choose to observe it. ${ }^{18}$ Nations may be presumed to consent to the voluntary law of nations, making it in a sense "positive" law, but treaty law and customary law, while both positive law as to those who choose to accept them, are also "arbitrary," and therefore subordinate to the necessary and voluntary law of nations. ${ }^{19}$ The will and desires of the separate states and sovereigns deserve respect under this traditional conception of the law of nations, but may not violate fundamental and the "necessary" principles of international law. ${ }^{20}$

The distinguishing feature of treaty and custom as the "positive" and "arbitrary" law of nations under general international law is their limited and subordinate authority as sources of law. Although he mentioned both treaty and custom in his treatise on the law of nations, Vattel also described them as secondary, partial, and inconstant forms of law, applying only between those states that choose to embrace them. ${ }^{21}$ The true value of "positive" treaty and customary law was their possible use as evidence of the underlying "necessary" and "voluntary" law of nations. The fact that the governments of disparate states can agree to particular treaties or customs is good evidence that these do in reality constitute reasonable solutions to the problems of international society. ${ }^{22}$

\section{Legal Positivism}

The value of legal positivism arises from its commitment to clarity and legal certainty, both highly desirable in human affairs. ${ }^{23}$ If international law rests-as it always has done and ultimately must do-on "reason" and "the nature of human society," there will be many occasions for "fragmentation" or interpretive confusion that "definitions" and "modifications" may do much to alleviate ${ }^{24}$ But there is also a persistent danger in positivism, present already in the work of Thomas Hobbes, the first great legal positivist, who "malgré ses paradoxes

${ }^{13}$ VATTEL, supra note 9 , at xvii.

${ }^{14}$ Id. at xix.

${ }^{15}$ Id., préliminaires $\$ 7$, at 4 .

${ }^{16}$ Id., préliminaires $\$ 21$, at $11-12$.

${ }^{17}$ Id., préliminaires, $\$ 24$, at 13 .

${ }^{18} I d$., préliminaires $\$ 25$, at 14 .

${ }^{19} \mathrm{Id}$., $\$ 27$, at 15 .

${ }^{20} \mathrm{ld}$., préliminaires, $\$ 9$, at 5 ( “[T] nécessaire prescrit, ou défend, sont illégitimes.').

21 "'Le detail des différens Traités et des diverses Coûtumes des Peuples appartient à l'Histoire, et non pas à un Traité Systématique du Droit des Gens." Id. at xxii.

22 WheAton, supra note 5 , at $23 \mathrm{ff}$.

${ }^{23}$ See H.L.A. Hart, Positivism and the Separation of Law and Morals, 71 HARv. L. REv. 593 (1958), on the desirability of being clear, even when one is "clearly wrong."

${ }^{24}$ See, e.g., Fragmentation of International Law: Difficulties Arising from the Diversification and Expansion of International Law, Report of the Study Group of the International Law Commission finalized by Marti Koskenniemi, UN Doc. A/CN.4/L.682/Add.1 (May 2, 2006). 
et ses maximes détestable" (Vattel), ${ }^{25}$ had acute perception and a facility with words. ${ }^{26}$ Positivism runs the risk of elevating clarity above justice-and by separating the law from justice of defeating the entire enterprise. ${ }^{27}$ Thomas Hobbes was very frank in asserting that "the notions of Right and Wrong, Justice and Injustice have . . no place" when (as with sovereign states) there is no supreme power to rule them: "[W]here there is no common Power, there is no law."28

If Hobbes, Austin, and H.L.A. Hart were each in his own generation the leading positivist critic of international law, the doctrine of international law itself continued to develop in practice and through the writings of such leading publicists as Hugo Grotius, Emer de Vattel, and Henry Wheaton-and ultimately the United Nations Charter. ${ }^{29}$ Proponents of international law since Grotius and Vattel have founded their efforts on basic truths easily recognized by anyone reasonable and therefore readily accepted by every person of good faith. ${ }^{30}$ Vattel and the others based their conception of international law on the normative power of justice, and understood the law of nations as a permanent constraint on sovereigns, in the interest of humanity as a whole. ${ }^{31}$

More sophisticated modern positivists have refined the positivist "separation thesis"separating the law from justice-into the more palatable "normal justification thesis," which holds that legal and other authority is justified only when it brings subjects into closer compliance with the reasons that should guide them, than they would be if they reasoned for themselves. ${ }^{32}$ Thus formulated, the normal justification thesis captures the possible benefits of legal positivism for international legal theory and for international legal institutions. ${ }^{33}$ "Positive" law is useful and binding on states and other international legal actors only when the institutions that purport to "posit" the law or to determine its content are more likely to reveal what the law actually requires-the dictates of reason and justice in international society-than their putative subjects would, when reasoning for themselves.

Some modern positivists see "law" as a matter of social fact, concerning those rules and institutions that societies believe will best reveal the requirements of reason and justice (regardless of whether they do so in reality). ${ }^{34}$ This further refinement of the normal justification thesis may be illuminating when powerful and highly self-confident elites have established strong formal and unitary coercive mechanisms to impose their world view through assertions

25 VATTEL, supra note 9 , at $\mathrm{X}$.

${ }^{26}$ Cf. 3 John Adams, Defence of the Constitutions of Government of the United States of America 211 (1788) ("a man, however unhappy in his temper, or detestable for his principles, equal in genius and learning to any of his contemporaries.").

${ }^{27}$ For the modern positivist commitment to the separation of law from morality, see, for example, Hart, supra note 23.

${ }^{28}$ Thomas Hobbes, Leviathan: Or the Matter, Forme and Power of a Commonwealth Ecclesiasticall AND Civill pt. I, ch. XIII, at 63 (1651).

${ }^{29}$ UN Charter, pmbl. ("to establish conditions under which justice and . . international law can be maintained."). Cf. Universal Declaration of Human Rights, pmbl., GA Res. 217 (III) A, UN Doc. A/RES/217(III) (Dec. 10, 1948) ("Whereas recognition of the inherent dignity and of the equal and inalienable rights of all members of the human family is the foundation of freedom, justice and peace in the world.").

${ }^{30}$ VatTEL, supra note 9, at xxiii ("Il me suffit de persuader: et pour cet effet, de ne rien advancer comme Principe, qui ne soit facilement admis par toute personne raisonable.").

${ }^{31}$ Vattel's response to Hobbes was unequivocal. Id. at Xxv ("Si de lâches flatteurs du Despotisme s'élèvent contre mes principes, j'aurai pour moi les hommes vertueux, les gens du coeur, les amis des Lois, les vrais Citoyens."').

32 Joseph Raz, The Morality of Freedom 53 (1986).

${ }^{33}$ Cf. John Tasioulas, The Legitimacy of International Law, in The Philosophy of INTERNational LAw 97 (Samantha Besson \& John Tasioulas eds., 2010).

${ }^{34}$ See, e.g., Joseph Raz, The Authority of Law: Essays on Law and Morality 37 (1979). 
of "law." No such power exists to promulgate international law. International law in its present state seeks to constrain the powerful by articulating the actual requirements of reason and justice, applied to the society of states. There is no widely shared belief in the justice or legitimacy of existing international institutions, and assertions of international law must therefore establish their authority through persuasion, by actually satisfying the normal justification thesis. Authority follows legitimacy, not vice versa.

\section{Confronting CompleXity}

The whole history of international law, from Hugo Grotius to the United Nations Charter, has been the search to specify and implement "those rules of conduct, which reason deduces, as consonant to justice, from the nature of the society existing among independent nations." Yet reason is evasive, justice depends on circumstances, and the society of independent nations remains disorganized and divided. No one has exclusive authority to "posit" international law-not even the Security Council when acting under Chapter VII, as the European Court of Justice (for example) insisted when it defied the United Nations in the Kadi case. ${ }^{35}$ Those who would clarify the complexity of international law must develop techniques for making the law more determinate. This requires finding (or constructing) institutions with the epistemic legitimacy required to posit international law.

Legal positivism can play a useful role in clarifying the content of international law, but only when it satisfies the normal justification for any legal institution: that it makes law's justice more certain and secure. International conventions, international custom, judicial decisions, and the teachings of the most highly qualified publicists are all very good evidence of general international law, but they are positive law only as to those that accept them as such and even then subject to the usual normative constraints. When international legal institutions become more democratic, balanced, liberal, and just, then positive law will matter more, and positivists will have their day in the sun. Until then, international lawyers must continue as before to rely on reason and good faith, and hope for better days to come.

\footnotetext{
${ }^{35}$ Kadi \& Al Barakaat v. Council of the EU Commission, Joined Cases C-402/05 P \& C-415/05 P, 3 WLR 872 [2009].
} 
